\begin{tabular}{lr}
\hline Jurnal Abdimas llmiah & JURNAL ABDIMAS ILMIAH CITRA BAKTI \\
Citra Bakti & Volume 2, Nomor 2, November 2021 \\
$(\mathrm{JAICB})$ & \\
\hline
\end{tabular}

\title{
PENDAMPINGAN BIMBINGAN BELAJAR MATA PELAJARAN MATEMATIKA BERBANTUAN ALAT PERAGA BAGI SISWA SEKOLAH DASAR DI KELURAHAN MATALOKO
}

\author{
Natalia Rosalina Rawa1), Melkior Wewe ${ }^{2)}$,Maria Carmelita Tali Wangge ${ }^{3)}$, Maria Editha \\ Bela $^{4)}$, Wilibaldus Bhoke ${ }^{5)}$, Florintina Elvin Bara ${ }^{6)}$, Veronika Meo ${ }^{7)}$ Oskarina Gelo ${ }^{8)}$, \\ Maria Bonifasia Pita Kosu', Maria Yoanita Ngina ${ }^{10}$
}

1,2,3,4,5,6,7,8,9,10)Program Studi Pendidikan Matematika, STKIP Citra Bakti

1)nataliarosalinarawa@gmail.com, 2)melkiorwewe@gmail.com,

3)carmelitawangge@gmail.com, ${ }^{4}$ itabella09@gmail.com, ${ }^{5)}$ wilibaldusbhoke87@gmail.com,

${ }^{6}$ elvin.bara90@gmail.com, 7)Veronikameo45@gmail.com, ${ }^{8)}$ osnnygello@gmail.com, 9)mariabpitakosu@gmail.com, 0)annitangina22@gmail.com

\begin{abstract}
Histori artikel
Received:

22 November 2021

Accepted:

26 November 2021

Published:

30 November 2021

Abstrak

Pengabdian kepada masyarakat ini dilatarbelakangi oleh siswa yang kemampuan belajar matematikanya rendah disebabkan oleh adanya pandemi Covid-19. Oleh karena itu, tujuan pengabdian kepada masyarakat mengadakan pendampingan bimbingan belajar bagi siswa sekolah dasar adalah untuk meningkatkan minat dan motivasi belajar siswa terhadap pembelajaran matematika. Hal ini didapat berdasarkan hasil wawancara dengan siswa-siswi selama kegiatan bimbingan belajar. Pendampingan siswa melalui kegiatan bimbingan belajar pada mata pelajaran matematika berbasis alat peraga dilakukan secara temu terbatas dan dilaksanakan di salah satu rumah penduduk di kelurahan mataloko.Kegiatan pendampingan belajar ini bertujuan untuk meningkatkan minat belajar siswa pada mata pelajaran matematika. Kegiatan pendampingan belajar juga bertujuan untuk menumbuhkan kembali semangat siswa yang menurun pada masa pandemi covid-19. Adapun metode yang digunakan dalam kegiatan bimbingan belajar yaitu metode ceramah dan metode diskusi. Metode ceramah dimulai dengan penjelasan materi secara lisan atau langsung kepada siswa. Metode diskusi dilakukan dengan kegiatan tanya jawab kepada siswa berkaitan dengan pemahaman siswa terhadap materi yang dijelaskan. Dengan adanya kegiatan bimbingan belajar ini dapat meningkatkan minat belajar siswa terhadap materi operasi hitung. Hal ini dilihat dari kemampuan respon siswa dalam proses kegiatan bimbingan belajar.
\end{abstract}

Kata-kata Kunci: bimbingan belajar, matematika, alat peraga 
Abstract. Education is important in various aspects of human life. Education can be obtained through formal, non-formal, and informal institutions. During the current covid-19 pandemic, non-formal education needs to be carried out to balance the online learning system which is considered less effective by students, especially elementary school student,specifically in mathematics. Therefore, the authors provide learning asisstance for elementary scholl student through tutoring activities. Tutoring is a learning activity carried out outside of school. Tutoring activities can be assisted by using teaching aids. Props are real objects and artificial objects used in learning activities. Student assistance through tutoring activities in teaching aids-based mathematics subjects is carried out in a limited meeting an carried out in one of the residents house in the Mataloko village. This learning mentoring activity aims to increase student's interest in learning mathematic. Learning mentoring activities also aim to rekindle the enthusiasm of students who declined during the covid-19 pandemic. The methods used in tutoring activities are the lecture method and the discussion method. The lecture method begins with and explanation of the material orally or directly to students. The method of discussion is carried out with question and answer activities to students related to students understanding of the material described. With this tutoring activity, it can increase student interest in learning about arithmetic operation. This can be seen from the student's response abillity in the process of tutoring activities.

Keywords: tutoring, mathematics, teaching aids

\section{PENDAHULUAN}

Bimbingan belajar sangat berperan penting bagi perkembangan belajar anak, karena tidak hanya apa yang diperoleh disekolah saja pembelajaran di luar sekolah juga memiliki dampak yang cukup besar dan berpengaruh bagi minat belajar siswa. Bimbingan belajar merupakan kegiatan belajar yang dilakukan diluar sekolah. Menurut Oemar Hamalik ( 2004 : 195 ) bimbingan belajar adalah bimbingan yang ditunjukan bagi siswa untuk mendapatkan pendidikan yang sesuai dengan kebutuhan akan minat, kemampuannya membantu siswa untuk menentukan cara yang efektif dan efisien dalam mengatasi masalah belajar yang dialami siswa. Kegiatan pendampingan siswa melalui bimbingan belajar sangat diperlukan dalam situasi pandemi covid-19 karena dianggap lebih efektif dibandingkan dengan pembelajaran daring.

Sepertinya yang sudah dijelaskan diatas bahwa bimbingan belajar adalah kegiatan belajar yang dilakukan diluar sekolah. Dalam mengikuti bimbingan belajar siswa diharapkan dapat menyelesaikan berbagai masalah proses belajar disekolah karena pada dasarnya banyak sekali keuntungan yang dapat diperoleh siswa dengan mengikuti bimbingan belajar seperti dapat meningkatkan minat belajar siswa untuk lebih memahami mata pelajaran yang dianggap sulit dan juga dapat meningkatkan prestasi siswa. Adapun tujuan dari bimbingan belajar adalah untuk membantu para siswa agar dapat menyelesaikan masalah kesulitan belajar disekolah dengan begitu aktifitas belajar mengajar akan lebih efisien sehingga dapat lebih optimal mengembangkan kemampuannya. Bimbingan belajar ini juga bertujuan untuk meningkatkan minat belajar siswa pada mata pelajaran matematika khususnya pada materi operasi hitung .

Sebagai ilmu pasti, matematika tidak pernah lepas dari kegiatan sehari-hari manusia. Oleh karena itu, penting sekali untuk menanamkan dasar-dasar ilmu matematika sejak awal pada peserta didik, seperti operasi hitung yang memuat penambahan, pengurangan, 
perkalian, dan pembagian. Sasaran pembelajaran matematika adalah siswa dapat mengimplementasikan pendidikan matematika yang didapatkan disekolah dalam kehidupan sehari-hari ataupun mempelajari berbagai pengetahuan lain (Rawa, dkk: 2020). Apabila peserta didik telah menguasai dasar-dasar ilmu matematika, sangat diharapkan dapat mempermudah peserta didik dalam memecahkan suatu masalah yang berkaitan dengan matematika dalam kehidupannya sehari-hari.

Dengan demikian, pembelajaran matematika bagi siswa Sekolah Dasar sendiri hendaknya dibuat lebih menyenangkan dan objeknya dari hal sederhana yang dekat dan digemari anak (Amalina, 2021: 546). Penyajian materinya harus dengan cara cara yang mudah dipahami sehingga dapat meningkatkan minat dan motivasi belajar siswa. Keberhasilan belajar matematika itu sendiri dapat dilihat dan diukur pada tingkat pemahaman serta penguasaan materi yang telah dipelajarinya. Semakin tinggi hasil belajarnya maka semakin tinggi pula prestasi belajar peserta didik.

Namun kenyataannya prestasi belajar matematika yang dicapai oleh siswa masih rendah (Nango, dkk, 2021). Data yang diperoleh dari the internasional mathematics and science study (TIMSS), lima tahun terakhir yaitu tahun 2015 menunjukkan prestasi belajar siswa di Indonesia mendapat peringkat 46 dari 51 negara dengan skor 397. Hal serupa juga degan data yang dihimpun oleh programme for international student assessment (PISA), kemampuan matematika siswa di Indonesia berada pada peringkat ke-63 dari 72 negara. Hal ini menunjukkan bahwa pembelajaran matematika perlu mendapat waktu belajar yang lebih banyak dan didukung dengan model, strategi ataupu media yang memadai.

Berdasarkan hasil wawancara dengan beberapa siswa di sekolah dasar di kelurahan Mataloko, terdapat permasalahan yang menyebabkan rendahnya hasil belajar matematika siswa, yaitu: kurang minatnya siswa pada mata pelajaran matematika, kurangnya keterampilan berhitung siswa, banyak siswa yang nilai matematikanya berada di bawah KKM, siswa tidak siap dalam menerima materi pembelajaran yang disampaikan serta metode belajar yang dilakukan secara konvensional.

Dari permasalahan tersebut, pembelajaran menggunakan alat peraga dalam pembelajaran matematika merupakan metode yang paling disarankan. Anak-anak dirasakan mengikuti pembelajaran dengan gembira, yang mengakibatkan siswa lebih aktif yang membuat minta belajar mereka menjadi meningkat. Lebih lanjut sajian objek abstrak matematika pada alat peraga ,membuat siswa lebih memahami konsep dan teori yang dipelajari (Murdiyanto \& Mahatma, 2014:40). Siswa-siswa yang berdomisili di Kelurahan Mataloko yang menjadi tempat kegiatan pengabdian masyarakat tengah dihadapi tantangan yang sama, di mana mereka diharuskan belajar dari rumah dan paling dominan tengah mempelajari materi operasi hitung. Maka, salah satu alat peraga yang di gunakan dalam pengabdian ini adalah alat peraga tabel penjumlahan dan perkalian. Penggunaan alat peraga 
tabel penjumlahan dan perkalian ini diharapkan dapat membuat pembelajaran matematika menjadi lebih bermakna, mempermudahkan siswa mengerjakan soal matematika yang berkaitan dengan materi operasi hitung serta dapat meningkatkan minat dan hasil belajar siswa pada mata pelajaran matematika.

\section{METODE PELAKSANAAN}

Kerangka kegiatan pengabdian ini dijabarkan pada bagan yang ditunjukkan pada gambar 1.

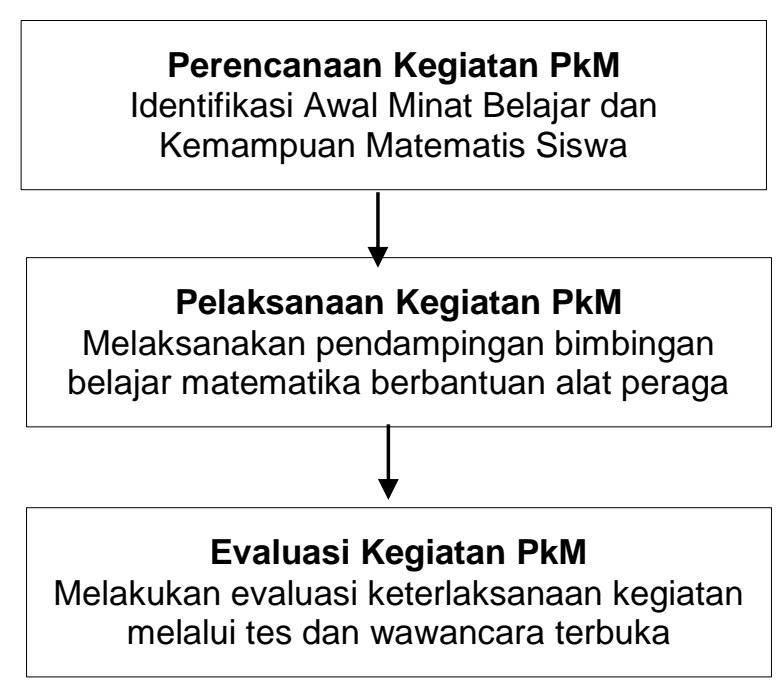

Gambar 1. Bagan Kerangka Kegiatan PkM (diadopsi dari Rawa, dkk, 2021)

1. Tahap Perencanaan

Kegiatan pengabdian kepada masyarakat ini merupakan salah satu bagian program kerja KKN 2021 yakni Asistensi Mengajar. Identifikasi awal dilaksanakan pada hari pertama kegiatan KKN melalui pendataan siswa sekolah dasar di kelurahan mataloko. Setelah diperoleh data sebaran siswa sekolah dasar di keluaran mataloko dilakukan wawancara terbuka dengan temu terbatas pada siswa sasaran untuk mengetahui informasi awal terkait minat belajar matematika dan juga kemampuan matematis siswa.

\section{Tahap Pelaksanaan}

Pendampingan siswa melalui kegiatan bimbingan belajar ini dilakukan secara temu terbatas dan dilaksanakan di salah satu rumah penduduk di Kelurahan Mataloko. Adapun metode yang digunakan dalam kegiatan bimbingan belajar ini adalah metode ceramah, metode diskusi dan metode pendampingan. Metode ceramah merupakan suatu bentuk penyajian bahan pengajaran melalui penerangan dan penuturan lisan oleh guru kepada siswa tentang suatu topik materi. 
Menurut Abuddin Nata, "bahwa metode ceramah adalah cara penyajian pelajaran yang dilakukan oleh guru dengan penuturan atau penjelasan secara langsung dihadapan peserta didik. Dalam ceramahnya guru dapat menggunakan alat bantu/alat peraga seperti gambar, benda, barang tiruan dan lain-lain. Dalam metode ini peran siswa adalah mendengarkan dengan teliti serta mencatat pokok penting yang dikemukakan oleh guru yang adalah mahasiswa KKN STKIP Citra Bakti Ngada. Metode ini dipilih dan digunakan karena siswa pada usia Sekolah Dasar masih suka mendengar cerita dan masih belum bisa bergerak aktif tanpa bimbingan dan arahan dari guru.

Metode diskusi merupakan cara-cara penyampaian bahan pelajaran yang mana guru memberikan kesempatan kepada sisiwa untuk mengadakan perbincangan ilmiah, mengemukakan pendapat, dan menyusun kesimpulan atau menemuan berbagai alternative pemecahan masalah.diskusi adalah percakapan ilmiah yang responsive berisikan pertukaran pendapat yang dijalin dengan pertanyaanpertanyaan problematik pemunculan ide-ide ataupun pendapat dilakukan oleh beberapa orang yang tergabung dalam kelompok yang diarahkan untuk memperoleh pemecahan masalah dan untuk mencari kebenaran (Sagala, 2003). Dengan metode diskusi, siswa diberikan kesempatan untuk mengembangkan ketrampilan memecahkan masalah, melatih dan membiasakan untuk bermusyawarah, serta menentukan keputusan bersama-sama.

Selanjutnya dilakukan metode pendampingan. Metode pendampingan belajar yang digunakan adalah dengan cara yang menarik. Tujuan dari pendampingan ini untuk meningkatkan prestasi belajar dan motivasi belajar siswa. Metode ini diakukan dengan masing-masing mahasiswa yang mendampingi satu atau dua siswa untuk membantunya memahami materi yang sudah dijelaskan sebelumnya.

3. Tahap Evaluasi

Evaluasi pelaksanaan kegiatan adalah (a) menganalisis minat belajar matematika siswa melalui wawancara terbuka setelah mengikuti kegiatan pendampingan bimbingan belajar berbantuan alat peraga, (b) menganalisis kemampuan matematis siswa melalui tes. Indikator keberhasilan kegiatan didasarkan pada meningkatnya minat belajar matematika dan hasil belajar siswa secara klasikal mencapai nilai lebih dari $70 .$.

\section{HASIL DAN PEMBAHASAN}

Hasil dari kegiatan pendampingan siswa dalam kegiatan bimbingan belajar yang dilaksanakan di salah satu rumah warga di Kelurahan Mataloko. Kegiatan pendampingan ini merupakan salah satu program pengabdian mahasiswa KKN bagi masyarakat sebagai upaya pelaksanaan tri dharma perguruan tinggi. Kegiatan bimbingan belajar ini dilaksanakan setiap hari Rabu yaitu 4 kali dalam sebulan secara temu terbatas dengan tetap memperhatikan 
protokol kesehatan. Sasaran dari kegiatan pendampingan bimbingan belajar ini yaitu 4 siswa SDK Mataloko, atas nama Deren, Indah, Vika,dan Jelita.

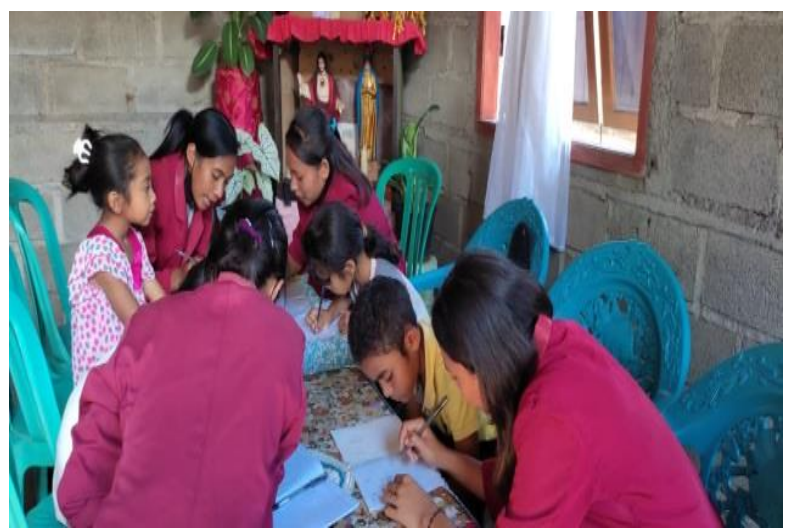

Gambar 2. Pendampingan Belajar Siswa

Dalam pelaksanaannya, pada tahap awal guru/tutor (mahasiswa KKN) dengan metode ceramah memberikan penjelasan dan pemahaman tentang konsep dasar matematika pada materi operasi hitung. Usaha ini dapat dibantu dengan menggunakan alat peraga matematika. Karena pada kenyataannya di lapangan masih banyak dijumpai siswa yang belum terampil dalam pengerjaan operasi hitung. Hal ini disebabkan karena siswa masih belum bisa menghafal perkalian dasar. Berdasarkan permasalahan tersebut, mahasiswa KKN mencoba menerapkan penggunaan alat peraga tabel perkalian sebagai upaya agar siswa lebih memahami konsep operasi hitung dan menjadikan pembelajaran matematika sebagai hal yang menyenangkan.

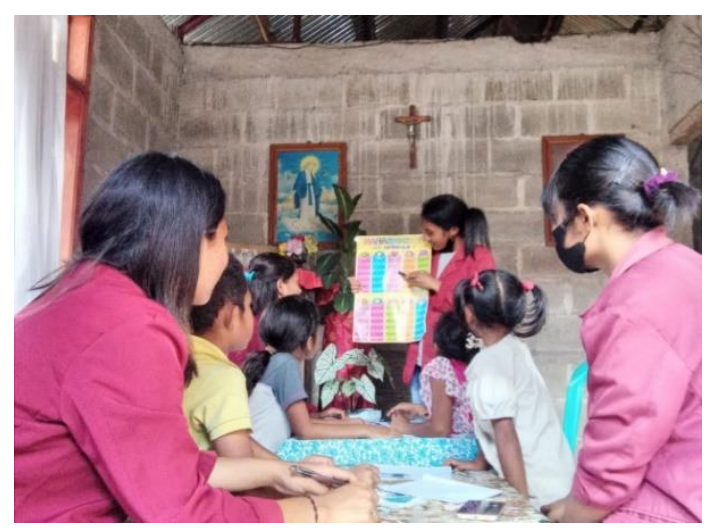

\section{Gambar 3. Penggunaan Alat Peraga Matematika Tabel Perkalian}

Setelah kegiatan penjelasan selesai, mahasiswa KKN mengajak siswa melakukan diskusi dengan memberi beberapa latihan soal materi operasi hitung yakni soal penjumlahan, pengurangan, perkalian, dan pembagian. Karena jumlah peserta bimbingan belajar sebanyak 4 siswa maka setiap satu orang mahasiswa KKN mendampingi satu orang siswa. Dalam kegiatan diskusi ini, siswa menggunakan alat peraga berupa tabel perkalian dan penjumlahan untuk membantunya menemukan jawaban dari soal yang diberikan dengan mudah,cepat dan 
tepat. Mahasiswa KKN juga mengajarkan cara melakukan perhitungan penjumlahan dan perkalian dengan menggunakan jari tangan apabila tidak terdapat alat peraga.

Dalam hal pemanfaatan alat peraga dalam kegiatan bimbingan belajar ini, ada sebagian siswa yang pembelajarannya menggunakan alat peraga dan ada juga siswa yang tidak menggunakan alat peraga. Siswa yang pembelajarannya menggunakan alat peraga tingkat pemahaman materinya lebih meningkat dan semangat belajarnya luar biasa terlebih khusus pada materi operasi hitung. Sedangkan siswa yang tidak menggunakan alat peraga tingkat pemahaman materi operasi hitung sedikit berkurang dari yang menggunakan alat peraga. Hal ini dilihat dari tes kemampuan siswa dalam menjawab dan mengerjakan latihan soal yang diberikan guru. Siswa yang menggunakan alat peraga mendapat nilai rata-rata sebesar 88,18 sedangkan siswa yang pembelajaran tanpa alat peraga mendapat nilai ratarata yang lebih kecil yaitu 80,71. Dari uraian tersebut, dapat dipahami bahwa pembelajaran matematika dengan alat peraga dapat meningkat hasil belajar siswa.

Berdasarkan data-data yang dijelaskan diatas, maka mahasiswa KKN akan memaparkan temuan hasil dari bimbingan belajar dengan menggunakan alat peraga pada siswa sekolah dasar di kelurahan Mataloko yaitu:(1). Hasil belajar siswa meningkat;(2). Dapat meningkatkan keaktifan siswa; (3). Penggunaan alat peraga dalam pembelajaran dengan melibatkan siswa dapat memudahkan siswa dalam mengingat pelajaran.

\section{KESIMPULAN}

Simpulan yang dapat diambil adalah kegiatan pendampingan bimbingan belajar bagi siswa sekolah dasar di kelurahan Mataloko dapat berlangsung dengan lancar. Keberhasilan kegiatan ini dapat dilihat dari terlibantunya kegiatan bimbingan belajar di rumah dan antusias anak-anak dalam mengikuti kegiatan pendampingan belajar serta dalam menerapkan perilaku hidup baru dan sehat dalam mencegah penyebaran covid-19. Berdasarkan hal tersebut, maka pendampingan bimbingan belajar sebaiknya dilakukan secara temu terbatas dan berkesinambungan sebagai upaya membantu orang tua dan anak-anak dalam mengatasi kesulitan belajar dan mencegah penyebaran virus covid-19.

Melalui kegiatan pengabdian kepada masyarakat ini, diharapkan agar semua siswasiswi mendapatkan ilmu pengetahuan yang belum dipahami selama kegiatan bimbingan. Diharapkan juga kepada guru untuk menjelaskan kembali disekolah dengan cara melaksanakan pembelajaran secara temu terbatas terlebih khusus mata pelajaran matematika menggunakan alat peraga yang lebih menunjang kegiatan pembelajaran dengan memperhatikan protokol kesehatan. Siswa-siswi kelurahan mataloko terlihat sangat antusias selama mengikuti bimbingan belajar, hal ini terlihat dari kehadiran dan respon baik siswa selama bimbingan belajar. Mereka juga tidak segan bertanya kepada mahasiswa yang membimbing mengenai materi yang belum mereka pahami. Pelaksanaan kegiatan pengabdian ini berjalan dengan baik dan lancar. 


\section{DAFTAR PUSTAKA}

Amrillah, M.A. (2021). Bimbingan belajar dari rumah dalam meningkatkan minat belajar anak sekolah di desa pacar kecamatan tirto kabupaten pekalongan.https://KKN.unes.ac.id/lapkk unes/32004-3326152010-6-Desa \%20 Pacar-20201003-004836.pdf https://scribe.com/dpc/291913144/Penggunaan Alat Peraga Perkalian-docx diakses pada tanggal 10 November 2021.

Bela, Maria Editha. (2018). Pembelajaran kontekstual untuk materi sistem persamaan linear dua variabel di kelas X siswa SMK. Jurnal Pendidikan Citra Bakti.

Bhoke, W.(2020). Teori dan implementasi pembelajaran matematika dengan media LKS. Makasar: Yayasan Barcode.

Murdiyanto, T.\& Mahatma, Y. (2014). Pengembangan alat peraga matematika untuk meningkatkan minat dan motivasi belajar matematika siswa sekolah dasar. Sarwahita: Jurnal Pengabdian Kepada Masyarakat.11(1), 38-43

Nango, P., Rawa, N. R., \& Wangge, M.C.T. (2021). Pengembangan bahan ajar geometri ruang sisi lengkung berbasis model learning cycle 7e terintergrasi konten budaya lokal ngada pada siswa SMP. Jurnal IImiah Pendidikan Citra Bakti, 8(2), 289-301. doi: https://doi.org/10.38048/iipcb.v8i2.351

Nasution, H.F. (2021). Peningkatan hasil belajar matematika melalui bimbingan belajar gratis. Indonesian Journal Of Community Service.1(1),66-73

Rawa, N.R., Laksana, D.N.L., \& Nurfahrudianto, A. (2021). Sharing session: pencegahan tindakan plagiarisme dalam penulisan karya ilmiah mahasiswa STKIP citra bakti. Selaparang: Jurnal Pengabdian Masyarakat Berkemajuan, 4(3), 607-612.

Rawa, N. (2020). Pengembangan lembar kegiatan siswa (LKS) matematika berbasis pendekatan scientific pada materi aritmatika sosial bagi siswa SMP. Jurnal Kependidikan: Jurnal Hasil Penelitian dan Kajian Kepustakaan di Bidang Pendidikan, Pengajaran dan Pembelajaran, 6(2), 319-328. doi:https://doi.org/10.33394/jk.v6i2.2620

Rawa, N. R., Bela, M. E., \& Pegi, M. J. (2021). Pengembangan bahan ajar geometri datar berbasis model learning cycle 7e untuk siswa SMP. Jurnal IImiah Pendidikan Citra Bakti, 8(1), 25-37. doi: https://doi.org/10.38048/jipcb.v8i1.132.

Sagala, S. (2003). Manajemen strategi dalam meningkatkan mutu pendidikan. Bandung: Alfabeta.

Wahyuningsih, B.Y. (2020). Efektifitas penggunaan alat peraga sederhana untuk meningkatkan aktivitas belajar siswa. Jurnal Keislaman dan IImu Pendidikan. 2(1):8496

Wangge,M.C.T.(2016). Pengembangan Perangkat Pembelajaran Matematika Realistik Untuk Meningkatkan Hasil Belajar Siswa Pada Persegipanjang Dan Persegi Kelas VII SMP. Tesis.

Wewe, M., \& H Kau.(2019). Etnomatika Bajawa: Kajian Simbol Budaya Bajawa Dalam Pembelajaran Matematika.Jurnal Ilmiah Pendidikan Citra Bakti 6(2), 121-219. 